ACTA UNIVERSITATIS WRATISLAVIENSIS

PRZEGLĄD PRAWA I ADMINISTRACJI CXX/2

WROCŁAW 2020

https://doi.org/10.19195/0137-1134.120.95

\author{
ELIZA MAZURCZAK-JASIŃSKA \\ ORCID: 0000-0003-2412-2427 \\ Uniwersytet Wrocławski \\ Instytut Prawa Cywilnego \\ Zakład Prawa Pracy
}

\title{
OCHRONA TRWAŁOŚCI ZATRUDNIENIA FUNKCJONARIUSZY SŁUŻB MUNDUROWYCH W PRZYPADKU REORGANIZACJI JEDNOSTEK ICH ZATRUDNIAJĄCYCH - WYBRANE ZAGADNIENIA
}

\begin{abstract}
Abstrakt: Przedmiotem opracowania jest problematyka ochrony trwałości niepracowniczych stosunków służbowych funkcjonariuszy służb mundurowych, których formacje mundurowe uległy w ostatnich latach głębokiej reorganizacji. Autorka dokonała krytycznej oceny przejściowych rozwiązań prawnych, mających na celu dostosowanie dotychczasowego zasobu kadrowego do aktualnych potrzeb i wymagań, wyłączających w istocie immanentną cechę zatrudnienia służbowego, jaką jest jego stabilizacja. W tym zakresie szczególną uwagę należało poświęcić zagadnieniom związanym $\mathrm{z}$ charakterem prawnym składanej funkcjonariuszowi przez właściwego przełożonego propozycji pełnienia służby lub zatrudnienia pracowniczego, lub informacji o braku oferty tego rodzaju oraz konieczności wydania decyzji rozwiązującej stosunek służbowy w razie jego przekształcenia w stosunek pracy na podstawie umowy na czas nieokreślony lub określony. Przedmiot oceny stanowi również dorobek orzeczniczy sądów administracyjnych powstały na tle przyjętych przez ustawodawcę rozwiązań prawnych we wskazanym zakresie.
\end{abstract}

Słowa kluczowe: stabilizacja zatrudnienia, funkcjonariusz służby mundurowej, wygaśnięcie stosunku służbowego, propozycja pełnienia służby lub zatrudnienia

\section{UWAGI WSTĘPNE}

Celem niniejszego opracowania jest analiza i ocena przyjętych przez ustawodawcę w ostatnim czasie rozwiązań prawnych, to jest ustawy z dnia 16 listopada 2016 roku - Przepisy wprowadzające ustawę o Krajowej Administracji Skarbowej $^{1}$ (dalej: ustawa wprowadzająca KAS) oraz ustawy z dnia 8 grudnia 2017 roku — o Służbie Ochrony Państwa ${ }^{2}$ (dalej: ustawa o SOP), a także powstałego na ich

1 Dz.U. z 2016 r. poz. 1948 z późn. zm.

2 Tekst jedn. Dz.U. z 2019 r. poz. 828 z późn. zm. 
tle dorobku judykatury, pod kątem ochrony trwałości niepracowniczych stosunków służbowych funkcjonariuszy formacji mundurowych, które w wyniku przyjęcia tych ustaw przeszły głęboką reorganizację. Efektem wprowadzenia tych regulacji była likwidacja Biura Ochrony Rządu oraz Służby Celnej i powstanie na ich zasobie kadrowym nowych formacji - Służby Ochrony Państwa oraz Służby Celno-Skarbowej. Celem nowych regulacji dotyczących administracji celno-skarbowej było przede wszystkim scalenie w jeden organizm administracji podatkowej, Służby Celnej i aparatu kontroli skarbowej. Niekorzystny audyt przeprowadzony w Biurze Ochrony Rządu uzasadniał natomiast, w ocenie autorów projektu ustawy o Służbie Ochrony Państwa, głęboką korektę obowiązującego stanu prawnego, mającą na celu gruntowną modyfikację funkcjonowania służby pod względem organizacyjno-prawnym, doprowadzającą do powstania zupełnie nowej formacji ochronnej ${ }^{3}$. Przeprowadzone reformy musiały doprowadzić do zmian personalnych, zmiany treści stosunków pracy i stosunków służbowych łączących dotychczas pracowników i funkcjonariuszy z likwidowanymi instytucjami. Ponieważ w obu nowych pragmatykach ustawodawca posłużył się podobnymi mechanizmami regulacyjnymi, zasadne jest scharakteryzowanie ich łącznie. Choć poruszana w artykule problematyka związana jest z przepisami przejściowymi, to dotyczy ważkich zagadnień związanych z gwarantowaną prawnie ochroną trwałości zatrudnienia podmiotów pozostających w niepracowniczych stosunkach służbowych.

\section{STABILIZACJA ZATRUDNIENIA FUNKCJONARIUSZY SŁUŻB MUNDUROWYCH}

Cechą charakterystyczną stosunku służbowego powstałego w wyniku mianowania do służby jest jego trwałość, w nauce określana również mianem stabilizacji. Przejawia się ona w enumeratywnym określeniu w ustawach pragmatycznych przesłanek mogących stanowić podstawę ustania stosunku służbowego funkcjonariusza służby mundurowej. Ustawodawca w poszczególnych pragmatykach, konstruując katalog tych przyczyn, określił skutki wystąpienia każdej z nich, kwalifikując je do zbioru obligatoryjnych lub fakultatywnych przesłanek zwolnienia. Tworząc zbiór podstaw zobowiązujących do zwolnienia, używa się zwrotu „funkcjonariusza zwalnia się ze służby". Istotą rozwiązania jest więc w tym przypadku istniejący po stronie właściwego przełożonego służbowego prawny obowiązek wydania, mającej charakter związany, decyzji w sprawie zwolnienia funkcjonariusza ze służby. Każda z podstaw obligatoryjnego zwolnienia ma tak duży ciężar gatunkowy, że uniemożliwia pozostawienie funkcjonariusza w dotychczasowej służbie. Jest to wspólna cecha wszystkich podstaw o tym charakterze mimo ich

${ }^{3}$ Zob. uzasadnienie rządowego projektu ustawy o Służbie Ochrony Państwa, druk sejmowy nr 1916. 
wywodzenia się z różnych zdarzeń i okoliczności ${ }^{4}$. Natomiast posłużenie się przez ustawodawcę zwrotem „można zwolnić” przesądza o uznaniowym charakterze decyzji w sprawie zwolnienia. Uznanie nie oznacza jednak dowolności. Organ administracyjny, działając w granicach uznania administracyjnego, zanim podejmie rozstrzygnięcie i zadecyduje, w jakim zakresie będzie korzystać ze swojej władzy, ma obowiązek wszechstronnego zbadania stanu faktycznego sprawy w perspektywie wszystkich przepisów prawa materialnego mogących mieć zastosowanie w sprawie ${ }^{5}$. Ramy uznania wyznacza zawsze przepis art. 7 k.p.a., a mianowicie interes społeczny (relatywizowany poprzez interes służbowy danej formacji) oraz słuszny interes funkcjonariusza. Badając legalność decyzji uznaniowej, sąd nie wnika w celowość jej wydania. Kontrola sądowa zmierza w tym wypadku jedynie do ustalenia, czy na podstawie przepisów prawa dopuszczalne było wydanie decyzji, czy organ przy jej wydawaniu nie przekroczył granic uznania i czy uzasadnił rozstrzygnięcie dostatecznie zindywidualizowanymi przesłankami 6 .

Wykładnia systemowa i celowościowa przepisów ustaw pragmatycznych zawierających obligatoryjne i fakultatywne podstawy zwolnienia ze służby wskazuje na pierwszeństwo stosowania przesłanek obligatoryjnych. W razie zaistnienia którejś z nich organ ma bezwzględny obowiązek zwolnienia ze służby. Wyłącznie w wypadku ich braku wchodzi w grę zastosowanie występujących przesłanek fakultatywnych.

Wszystkie pragmatyki służb mundurowych, poza ustawą o Policji, zawierają również zamknięte katalogi zdarzeń skutkujących wygaśnięciem niepracowniczego stosunku służbowego. Poszczególne regulacje różnią się, podobnie jak w wypadku rozwiązania, aczkolwiek nie tak znacznie, co do zakresu zdarzeń stanowiących podstawę wygaśnięcia.

\section{REGULACJE DOTYCHCZASOWE}

Status funkcjonariuszy Służby Celnej przed zmianami wynikającymi ze wskazanych regulacji unormowany był przede wszystkim w uchylonej ustawie z dnia 27 sierpnia 2009 roku o Służbie Celnej ${ }^{7}$ (dalej: ustawa o Służbie Celnej), natomiast funkcjonariuszy BOR w ustawie z dnia 16 marca 2001 roku o Biurze Ochrony Rządu ${ }^{8}$ (dalej: ustawa o BOR).

Stosunek służbowy funkcjonariusza tych służb powstawał w drodze mianowania dokonywanego przez szefa Służby Celnej (lub upoważnionego przez nie-

4 Por. wyrok NSA z dnia 9 maja 1997 roku, II SA 137/97, ONSA 1998, Nr 2, poz. 55.

5 Por. wyrok NSA z dnia 9 października 2001 roku, II SA 1075/01, Legalis; wyrok WSA w Warszawie z dnia 6 maja 2010 roku, II SA/Wa 332/10, www.nsa.gov.pl.

6 Por. wyrok NSA z dnia 16 grudnia 2010 roku, I OSK 962/10, Legalis.

7 Tekst jedn. Dz.U. z 2016 r. poz. 1799 z późn. zm.

8 Tekst jedn. Dz.U. z 2017 r. poz. 985 z późn. zm. 
go kierownika urzędu) lub odpowiednio szefa BOR na podstawie dobrowolnego zgłoszenia się do służby (por. art. 78 ust. 1 oraz art. 82 ust. 1 ustawy o Służbie Celnej oraz art. 23 ust. 1-2 w zw. z art. 25 ust. 1 ustawy o BOR). W normatywnie określonych granicach dyspozycyjności stosunek służbowy funkcjonariuszy mógł być przekształcany w drodze formalnie i materialnie jednostronnego aktu lub formalnie jednostronnego, a materialnie dwustronnego aktu właściwych przełożonych służbowych. Do zmiany tych stosunków mogło dochodzić również na skutek wniosku o przeniesienie złożonego przełożonemu przez funkcjonariusza oraz wskutek jego zawieszenia w pełnieniu obowiązków. Ustanie stosunku zatrudnienia funkcjonariusza służby celnej następowało w wyniku rozwiązania stosunku służbowego lub jego wygaśnięcia. Publicznoprawny charakter stosunku zatrudnienia we wskazanych formacjach mundurowych determinował przyjęty w pragmatykach sposób regulacji tej instytucji. Rozwiązanie następowało zawsze w wyniku wydania, mającego konstytutywny charakter, jednostronnego aktu uprawnionego organu o zwolnieniu ze służby, nawet gdy stroną inicjującą rozwiązanie był sam funkcjonariusz zgłaszający wystąpienie ze służby.

Konsekwencją administracyjnego charakteru zatrudnienia funkcjonariuszy służb mundurowych, w tym funkcjonariuszy zlikwidowanych służb, jest zasada, zgodnie z którą roszczenia wynikające $\mathrm{z}$ decyzji właściwych przełożonych służbowych mających wpływ na przekształcenie lub rozwiązanie stosunku służbowego dochodzone są $\mathrm{w}$ trybie przepisów postępowania administracyjnego z uwzględnieniem możliwości złożenia na ostateczną decyzję przełożonego skargi do sądu administracyjnego ${ }^{9}$. Poddanie sporu pod rozstrzygnięcie sądu administracyjnego wymagało zatem wyczerpania drogi instancyjnej w postępowaniu administracyjnym.

Należy podkreślić, że konstrukcja zmiany i ustania stosunku służbowego funkcjonariuszy Służby Celno-Skarbowej oraz funkcjonariuszy Służby Ochrony Państwa, jak również procedury kontroli instancyjnej zasadniczo nie odbiega od sposobu ukształtowania jej $\mathrm{w}$ dotychczasowych regulacjach ${ }^{10}$. Podobnie jak w przypadku ustawy o Służbie Celnej (ustawy o BOR) spory w zakresie zmiany i rozwiązania, a także wygaśnięcia stosunku służbowego funkcjonariuszy Służby Ochrony Państwa poddane zostały kontroli instancyjnej z możliwością wniesienia skargi do sądu administracyjnego. Spory o roszczenia ze stosunku służbowego funkcjonariuszy Służby Celno-Skarbowej w sprawach innych niż zmiana i rozwiązanie stosunku służbowego rozpatruje sąd właściwy w sprawach z zakresu pra-

9 Z wyjątkiem spraw wynikających ze stwierdzenia wygaśnięcia stosunku służbowego funkcjonariuszy Służby Celnej; zob. art. 188 w zw. z art. 189 ustawy o Służbie Celnej; oraz wyrok WSA w Warszawie z dnia 29 czerwca 2011 roku, II SA/Wa 891/11, LEX nr 1086976; wyrok NSA z dnia 17 grudnia 1985 roku, III SA 988/85,ONSA 1985/2/38; postanowienie NSA z dnia 17 maja 2012 roku, I OSK 2023/11, LEX nr 1282164. Ustawa o BOR nie przewidywała wygaśnięcia jako jednego ze sposobów ustania stosunku służbowego.

10 Zob. jednak art. 276 i art. 277 ustawy z dnia 16 listopada 2016 roku o Krajowej Administracji Skarbowej (tekst. jedn. Dz.U. z 2019 r. poz. 768 z późn. zm.). 
wa pracy (por. art. 276 i art. 277 ustawy o KAS). Oznacza to, że przepis art. 277, podobnie jak w poprzednim stanie prawnym art. 189 ustawy o służbie celnej, stanowi podstawę dochodzenia przez funkcjonariusza Służby Celno-Skarbowej roszczeń związanych z wygaśnięciem stosunku służbowego przed sądem pracy ${ }^{11}$.

\section{REGULACJE PRZEJŚCIOWE}

Na mocy przepisów wprowadzających ustawę o KAS oraz przepisów przejściowych ustawy o SOP mających na celu między innymi dostosowanie sfery zatrudnienia $\mathrm{w}$ instytucjach objętych zakresem działania wskazanych regulacji do nowych realiów prawnych dotychczasowe unormowania dotyczące zmiany i ustania niepracowniczego stosunku służbowego typu administracyjnego funkcjonariuszy Służby Celnej i BOR zostały rozszerzone o dodatkowe zdarzenia prawne, z których wystąpieniem ustawodawca powiązał skutki w postaci zmiany (przekształcenia) lub ustania tych stosunków. Posłużenie się przez ustawodawcę nowymi instytucjami ingerującymi w dotychczasowe stosunki służbowe funkcjonariuszy oraz ich ocena dokonana w orzecznictwie sądów administracyjnych w sposób istotny wpłynęły na zakres ochrony trwałości zatrudnienia funkcjonariuszy likwidowanych formacji.

Na podstawie przepisu art. 165 ust. 6 ustawy wprowadzającej KAS funkcjonariusze celni pełniący służbę w izbach celnych, nie później niż do dnia 28 lutego 2017 roku, mieli otrzymać pisemną informację o miejscu wykonywania obowiązków służbowych, jeżeli ulegało ono zmianie. Brak informacji w tym terminie był równoznaczny z powierzeniem wykonywania obowiązków służbowych w dotychczasowym miejscu. Funkcjonariusze pełniący służbę w BOR w dniu wejścia w życie ustawy o SOP stali się odpowiednio funkcjonariuszami SOP z utrzymaniem dotychczasowych warunków służby lub pracy, zachowując ciągłość służby lub pracy (por. art. 359 ust. 1 ustawy o SOP).

Natomiast zgodnie z przepisem art. 165 ust. 7 ustawy wprowadzającej KAS dyrektor Krajowej Informacji Skarbowej, dyrektor Izby Administracji Skarbowej oraz dyrektor Krajowej Szkoły Skarbowości mogli złożyć funkcjonariuszom, w terminie do dnia 31 maja 2017 roku, pisemną propozycję określającą nowe warunki zatrudnienia albo pełnienia służby, która miała uwzględniać posiadane kwalifikacje i przebieg dotychczasowej pracy lub służby, a także dotychczasowe miejsce zamieszkania. Komendant SOP mógł złożyć pisemną propozycję określającą nowe warunki pełnienia służby albo pracy lub warunki płacy w terminie dwóch miesięcy od dnia wejścia w życie ustawy o SOP. Propozycja miała uwzględniać przebieg służby w BOR oraz przydatność do służby w SOP, a także inne wymagania stawiane funkcjonariuszom nowo utworzonej formacji, które określono

11 Zob. postanowienie NSA z dnia 17 maja 2012 roku, I OSK 2023/11, LEX nr 1282164. 
w przepisie art. 68 ustawy o SOP (por. art. 359 ust. 2 pkt 1 ustawy o SOP). Ze wskazanych regulacji wynika, że nie ma podstawy prawnej dla przyjęcia, że na organie właściwym spoczywał obowiązek przedstawienia funkcjonariuszowi likwidowanych formacji wyłącznie propozycji pełnienia służby ${ }^{12}$.

Funkcjonariusze, którym przedstawiono propozycję zatrudnienia albo pełnienia służby, mieli złożyć w terminie 14 dni od dnia jej otrzymania oświadczenie o przyjęciu albo odmowie przyjęcia propozycji. Niezłożenie oświadczenia w tym terminie było równoznaczne $\mathrm{z}$ odmową przyjęcia propozycji zatrudnienia albo pełnienia służby (por. art. 170 ust. 2 ustawy wprowadzającej KAS oraz art. 359 ust. 4 ustawy o SOP).

W wypadku przyjęcia propozycji pełnienia służby albo zatrudnienia dotychczasowy stosunek służby funkcjonariuszy w służbie przygotowawczej albo stałej $\mathrm{z}$ dniem określonym w propozycji przekształcał się odpowiednio w stosunek służby albo pracy w Służbie Celno-Skarbowej (SOP) na podstawie — odpowiednio — mianowania do służby przygotowawczej, służby stałej, umowy o pracę na czas nieokreślony albo określony (por. art. 171 ust. 1 ustawy wprowadzającej KAS oraz art. 359 ust. 7 ustawy o SOP).

Stosunki służbowe funkcjonariuszy likwidowanych formacji wygasały w wypadku nieotrzymania od właściwego przełożonego pisemnej propozycji określającej nowe warunki pełnienia służby albo pracy lub warunki płacy po upływie określonego przez ustawy czasu ${ }^{13}$ oraz po upływie 3 miesięcy, licząc od pierwszego dnia miesiąca następującego po miesiącu, w którym funkcjonariusz SOP złożył oświadczenie o odmowie przyjęcia propozycji służby lub pracy, jednak nie później niż dnia 31 sierpnia 2017 roku (KAS), nie później niż po upływie 5 miesięcy od dnia wejścia w życie ustawy o SOP. W obu formacjach wygaśnięcie stosunku służbowego funkcjonariusza ze wskazanych przyczyn traktowane było jak zwolnienie ze służby (zob. art. 170 ust. 3 ustawy wprowadzającej KAS oraz art. 359 ust. 8 ustawy o SOP).

W pragmatyce Służby Ochrony Państwa wyraźnie wskazano na obowiązek Komendanta SOP wydania rozkazu personalnego stwierdzającego wygaśnięcie stosunku służbowego. Ustawodawca nadał wskazanemu rozkazowi rygor natychmiastowej wykonalności oraz przekazał sprawy mogące z nich wyniknąć na drogę postępowania administracyjnego, co w konsekwencji powodowało możliwość ich kontroli $\mathrm{w}$ toku instancji z możliwością wniesienia skargi do sądu administracyjnego na ostateczne rozstrzygnięcie właściwego przełożonego (art. 359 ust. 9 ustawy o SOP).

12 Zob. między innymi wyrok NSA z dnia 17 stycznia 2019 roku, I OSK 996/18, LEX nr 2629767; wyrok WSA w Gdańsku z dnia 20 grudnia 2017 roku, III SAB/Gd 71/17, LEX nr 2417710 .

13 Pięć miesięcy od dnia wejścia w życie ustawy o SOP; z dniem 31 sierpnia 2017 roku w przypadku funkcjonariuszy Służby Celno-Skarbowej. 
Na obowiązek wynikający z domniemania załatwienia sprawy w formie decyzji, której podstawę prawną stanowił art. 170 ust. 3 ustawy wprowadzającej KAS w związku z art. 276 ust. 2 ustawy o KAS, wskazywało bogate orzecznictwo zarówno wojewódzkich sądów administracyjnych, jak i NSA ze skarg na bezczynność właściwych przełożonych w przedmiocie wydania decyzji dotyczącej stosunku służbowego ${ }^{14}$.

Dokonując analizy przyjętych rozwiązań ustawodawczych oraz oceny dorobku orzeczniczego powstałego w tym zakresie pod kątem ochrony trwałości zatrudnienia funkcjonariuszy służb mundurowych, szczególną uwagę należy poświęcić przede wszystkim regulacjom dotyczącym składanej tym podmiotom propozycji pełnienia służby lub zatrudnienia pracowniczego oraz informacji właściwego przełożonego o braku oferty tego rodzaju.

Z przepisów wprowadzających ustawę o KAS wyraźnie wynika, że propozycja pełnienia służby w Służbie Celno-Skarbowej stanowiła decyzję ustalającą nowe warunki jej wykonywania. Ustawodawca wprowadził kryteria merytoryczne, którymi powinien kierować się organ ją składający (por. art. 165 ust. 7 ustawy wprowadzającej KAS). Należały do nich: posiadane kwalifikacje, przebieg dotychczasowej służby, a także dotychczasowe miejsce zamieszkania. Ich zastosowanie musiało znaleźć odzwierciedlenie w uzasadnieniu decyzji w przedmiocie propozycji ustalającej nowe warunki pełnienia dalszej służby przez funkcjonariusza (art. 169 ust. 4 ustawy wprowadzającej KAS w związku z art. 107 § 1 pkt 6 i $\S 3$ ustawy z dnia 14 czerwca 1960 roku — Kodeks postępowania administracyjnego ${ }^{15}$. Organ powinien był w sposób przejrzysty, jawny i transparentny wykazać, że przy składaniu funkcjonariuszowi propozycji zastosował kryteria z art. 165 ust. 7 tej ustawy wprowadzającej KAS, które zostały określone w sposób wyczerpujący, a zatem nie mógł sięgać po inne pozaustawowe okoliczności, uzasadniając składane propozycje dalszej służby ${ }^{16}$. Funkcjonariusz w terminie czternastu dni od dnia jej przyjęcia mógł złożyć wniosek o ponowne rozpatrzenie sprawy, a ostateczna decyzja mogła stanowić przedmiot skargi w postępowaniu przed sądem administracyjnym (por. art. 169 ust. 4-7 ustawy wprowadzającej KAS). Należy podkreślić, że kontrola instancyjna wraz z możliwością wniesienia skargi mogła mieć miejsce zarówno w razie przyjęcia, jak i odrzucenia przez funkcjonariusza złożonej propozycji. Przyjęte przez ustawodawcę rozwiązania nadające czynności właściwego przełożonego funkcjonariusza Służby Celno-Skarbowej charakter decyzji administracyjnej zasługują na akceptację. Akt ten wpisuje się w schemat szeroko pojętej dyspozycyjności podmiotu pozostającego w niepracowniczym sto-

14 Zob. między innymi wyrok NSA z dnia 17 października 2019 roku, I OSK 1041/18, LEX nr 2738714; wyrok WSA w Opolu z dnia 26 lutego 2019 roku, II SAB/Op 3/19, LEX nr 2633420; Wyrok WSA w Łodzi z dnia 21 czerwca 2018 roku, III SAB/Ld 19/18, LEX nr 2521404.

15 Tekst jedn. Dz.U. z 2018 r. poz. 2096 z późn. zm.

16 Zob. wyrok WSA w Bydgoszczy z dnia 7 marca 2018 roku, II SA/Bd 1142/17, LEX nr 2475456. 
sunku służbowym o charakterze administracyjnym obejmującej w tym przypadku obowiązek funkcjonariusza poddania się formalnie jednostronnemu, a materialnie dwustronnemu aktowi zmieniającemu stosunek służbowy, podlegającemu finalnie kontroli sądu administracyjnego.

Niestety, na dokonanie podobnego zabiegu prawnego ustawodawca nie zdecydował się, regulując propozycję dalszego pełnienia służby składaną funkcjonariuszowi SOP. Zgodnie z pragmatycznymi regulacjami z przyjęciem propozycji pełnienia służby przez funkcjonariusza wiązał się obowiązek komendanta SOP wydania rozkazu personalnego o mianowaniu na stanowisko służbowe w SOP, do którego stosuje się przepisy k.p.a. (por. art. 359 ust. 10 i ust. 13 ustawy o SOP). W orzecznictwie sądów administracyjnych przyjęto, że pisemnej propozycji określającej warunki pełnienia służby w SOP nie można było uznać za decyzję administracyjną, ponieważ nie rozstrzygała ona żadnej indywidualnej sprawy administracyjnej. Nie była aktem lub czynnością, o której mowa w przepisie art. 3 $\S 2$ pkt 4 ustawy z dnia 30 sierpnia 2002 roku — Prawo o postępowaniu przed sądami administracyjnymi ${ }^{17}$ (dalej: p.p.s.a.). Przyjęto, podobnie jak w przypadku propozycji zatrudnienia złożonej funkcjonariuszowi Służby Celno-Skarbowej, że propozycja określająca warunki pełnienia służby nie ma charakteru władczego, ponieważ bezpośrednio nie kształtuje w sposób jednostronny praw i obowiązków skarżącego. Nie można zatem uznać jej za akt o charakterze zewnętrznym obejmującym władcze działanie organu z zakresu administracji publicznej. W ocenie sądu organ przedstawiający taką propozycję nie kształtuje jednostronnie praw i obowiązków podmiotu administracyjnego, niezależnie od jego woli. Propozycja nie rodzi żadnych wiążących konsekwencji, a organ administracji nie narzuca swojego stanowiska, które bezwzględnie należy zaakceptować jako jedynie słuszne. Skierowanie jej (pisemnej propozycji) do adresata jest jedynie przedstawieniem pewnego rozwiązania. To od woli adresata, a konkretnie treści złożonego przez niego oświadczenia, zależą dopiero dalsze działania organu ${ }^{18}$.

Trudno zaakceptować przedstawione przez sąd administracyjny argumenty. Podobnie jak w wypadku funkcjonariuszy Służby Celno-Skarbowej propozycja ta wpisuje się w schemat dyspozycyjności. Rozkazy personalne wpływające na modyfikację niepracowniczego zatrudnienia tradycyjnie, we wszystkich pragmatykach służbowych, w tym również w ustawie o SOP, przybierają postać aktu administracyjnego podlegającego kontroli $\mathrm{w}$ toku instancji z możliwością złożenia skargi na ostateczne rozstrzygnięcie do sądu administracyjnego (zob. art. $76 \mathrm{w}$ związku $\mathrm{z}$ art. 78 ustawy o SOP). Propozycja komendanta SOP powinna była przyjąć również i w tym wypadku postać formalnie jednostronnego, a materialnie dwustronnego aktu, w którego uzasadnieniu powinny znaleźć odzwierciedlenie wyraźnie wskaza-

17 Tekst jedn. Dz.U. z 2019 r. poz. 2325 z późn. zm.

18 Zob. postanowienie WSA w Warszawie z dnia 2 października 2018 roku, II SA/Wa 1382/18, LEX nr 2737589. 
ne przez ustawodawcę kryteria, którymi organ kierował się przy jego podejmowaniu (zob. art. 359 ust. 3 ustawy o SOP). Akt przełożonego miał charakter władczy, już na tym etapie rozstrzygający o braku możliwości kontynuacji zatrudnienia na dotychczasowych warunkach, mogący w efekcie stanowić przesłankę wygaśnięcia stosunku służbowego. Należy podkreślić, że akceptacja propozycji czyniłaby zbędnym wydawanie rozkazu personalnego o mianowaniu na stanowisko służbowe w SOP, ponieważ nowe warunki pełnienia Służby były określone w mającej charakter decyzji administracyjnej propozycji komendanta SOP.

Ustawodawca $\mathrm{w}$ żadnej z dwóch analizowanych pragmatyk nie zdecydował się nadać określonej formy prawnej propozycji określającej warunki zatrudnienia w charakterze pracownika, choć kryteria merytoryczne, którymi powinien kierować się organ ją składający, były identyczne z tymi, którym odpowiadać powinna była propozycja służby składana funkcjonariuszom tych formacji (por. art. 165 ust. 7 ustawy wprowadzającej KAS oraz art. 359 ust. 3 ustawy o SOP).

Zgodnie z linią orzeczniczą przyjętą przez Naczelny Sąd Administracyjny propozycja zatrudnienia na nowych warunkach nie stanowiła decyzji administracyjnej w rozumieniu przepisów k.p.a. ani aktu lub czynności, o jakich mowa $\mathrm{w}$ art. $3 \S 2$ pkt 4 p.p.s.a. ${ }^{19}$, a sprawa z nią związana pozostawała sprawą wewnętrzną z zakresu podległości służbowej, wobec czego wyłączona była spod kontroli sądowoadministracyjnej, w myśl art. 5 pkt 2 p.p.s.a. Nie miała ona również charakteru władczego, albowiem jej skutki prawne uzależnione były od woli jej adresata. Propozycja ta była ofertą zawarcia stosunku pracy na podstawie umowy o pracę, a organ ją przedkładający występował w charakterze pracodawcy, a nie jako organ administracji publicznej, a jego działania miały formę cywilnoprawną ${ }^{20}$.

Wbrew przyjętemu przez NSA stanowisku, propozycja zatrudnienia nie pozostawała sprawą wewnętrzną z zakresu podległości służbowej. W nauce prawa administracyjnego podległość służbowa rozumiana jest bowiem jako relacja zachodząca pomiędzy przełożonymi i podwładnymi w ramach wykonywania obowiązków służbowych i związana jest z wykonywaniem poleceń aktualizujących lub konkretyzujących obowiązki składające się na schemat stosunku służbowego i mieszczące się w nim. $Z$ całą stanowczością należy również podkreślić, że choć ostatecznie to zatrudniony podejmował decyzję w zakresie przyjęcia lub odmowy przyjęcia propozycji zatrudnienia, to organ już na etapie jej składania w sposób jednostronny i władczy ustalał nowe warunki pracy oraz, bez względu na decyzję podjętą przez funkcjonariusza, decydował o zakończeniu niepracowniczego stosunku służbowego. Podobnie jak w wypadku decyzji ustalającej warunki pełnienia służby, także w tym stadium postępowania relacja pomiędzy funkcjonariuszem

19 Zob. między innymi postanowienie NSA z dnia 30 stycznia 2018 roku, I OSK 2816/17, LEX nr 2588654; postanowienie NSA z dnia 14 lutego 2018 roku, I OSK 105/18, LEX nr 2447517.

20 Zob. między innymi wyrok NSA z dnia 17 stycznia 2019 roku, I OSK 996/18 Legalis nr 1882124; uchwała NSA z dnia 1 lipca 2019 roku, I OPS 1/19, ONSA i WSA z 2019 nr 5, poz. 71. 
pozostającym nadal w służbie a organem składającym ofertę pracy miała $\mathrm{w}$ dalszym ciągu charakter publicznoprawny. Relacja pracodawca-pracownik mogła pojawić się dopiero po zaakceptowaniu oferty pracy przez funkcjonariusza i ustaniu stosunku służbowego.

Propozycja pełnienia służby w wypadku jej przyjęcia wpisywała się w schemat szeroko pojętej dyspozycyjności obejmującej obowiązek funkcjonariusza poddania się formalnie jednostronnemu, a materialnie dwustronnemu aktowi zmieniającemu stosunek służbowy podlegającemu finalnie kontroli sądu administracyjnego. Propozycja zatrudnienia wykraczała zdecydowanie poza schemat modyfikacji treści tego stosunku. Była istotną częścią składową procesu prowadzącego do zmiany podstawy zatrudnienia skutkującego utratą statusu funkcjonariusza i nawiązaniem zdecydowanie mniej stabilnego, pracowniczego stosunku zatrudnienia na jednostronnie z góry określonych przez organ warunkach. Trudno zatem zaakceptować stan, w którym łagodniejsza w skutkach decyzja ustalająca nowe warunki pełnienia służby poddana została kontroli instancyjnej z możliwością złożenia skargi do sądu administracyjnego, natomiast propozycja zatrudnienia pracowniczego na ustalonych jednostronnie przez organ warunkach takiej kontroli byłaby pozbawiona. Tym bardziej, że brak jej akceptacji ze strony zatrudnionego powodował wygaśnięcie stosunku służbowego. Wyłączenie takiej czynności przełożonego służbowego spod kontroli sądu powoduje, że ewentualna sądowa kontrola decyzji wydawanych na skutek jej akceptacji lub odmowy przyjęcia byłaby pozorna i w żadnym wypadku nie zabezpieczałaby interesów podmiotu pozostającego w zatrudnieniu niepracowniczym. Dlatego też zasadnym byłoby nadanie ofercie tego rodzaju, jeżeli nie waloru decyzji administracyjnej, to przynajmniej charakteru czynności, o której mowa w art. $3 \S 2$ pkt 4 p.p.s.a. Przyjęcie takiego stanowiska umożliwiałoby kontrolę tego aktu w postępowaniu przed sądem administracyjnym. Warto podkreślić, że w orzecznictwie wojewódzkich sądów administracyjnych pojawiły się stanowiska opowiadające się za przyjęciem kognicji sądu administracyjnego w sprawach dotyczących funkcjonariuszy służby celnej w zakresie kontroli decyzji ${ }^{21}$ lub czynności, o której mowa w art. $3 \S 2$ pkt 4 p.p.s.a., wskazujące na konieczność ochrony funkcjonariusza przed arbitralnym działaniem organu administracyjnego zmierzającego do pozbawienia adresata oferty dalszego statusu osoby pełniącej obowiązki w Służbie Celno-Skarbowej poprzez obwarowanie propozycji zatrudnienia odpowiednimi gwarancjami o charakterze materialnoprawnym i proceduralnym. Gwarancje proceduralnej kontroli pozwalają na ocenę zachowania merytorycznych przesłanek uzasadniających złożenie określonej propozycji i mogłyby doprowadzić do złożenia funkcjonariuszowi pisemnej propozycji dalszego pełnienia służby 22 .

${ }^{21}$ Zob. wyrok WSA w Szczecinie z dnia 4 października 2017 roku, SA/Sz 897/17, LEX nr 2377612.

${ }^{22}$ Zob. wyrok WSA w Krakowie z dnia 15 lutego 2018 roku, III SA/Kr 1538/17, LEX nr 2453307. 
Dostrzegalne są również występujące w judykaturze rozbieżności dotyczące oceny charakteru prawnego aktu finalnie ,przekształcającego” stosunek służbowy w stosunek pracy. NSA konsekwentnie opowiada się za jego pracowniczym charakterem, który wraz z propozycją zatrudnienia jest bardziej zbliżony w swych następstwach do wypowiedzenia zmieniającego przewidzianego w kodeksie pracy niż do załatwienia sprawy w formie decyzji administracyjnej. W ocenie tego Sądu dotychczasowy stosunek służbowy funkcjonariusza Służby Celno-Skarbowej ulegał transpozycji w nowy i nie został zakończony, lecz zmieniony, co w konsekwencji nie wiąże się z obowiązkiem właściwego organu do wydania decyzji orzekającej o zakończeniu stosunku służbowego ${ }^{23}$. W orzecznictwie wojewódzkich sądów administracyjnych pojawiło się natomiast stanowisko, zgodnie z którym przyjęcie propozycji przez funkcjonariusza implikowało czynność organu polegającą na zwolnieniu ze służby na mocy decyzji administracyjnej. W ocenie sądów pierwszej instancji taka interpretacja regulacji pragmatycznych jest konieczna w sytuacji, w której wykładnia literalna nie daje rezultatu gwarantującego ochronę prawną funkcjonariuszy pozostających nadal w stosunkach służbowych ${ }^{24}$.

Należy podkreślić, że zasadniczym celem instytucji wypowiedzenia warunków pracy i płacy jest zmiana treści stosunku pracy, nie zaś jego podstawy. Już z tych względów nietrafne zatem jest porównanie tej instytucji do przekształcenia stosunku służbowego w stosunek pracy. Natomiast na gruncie regulacji pragmatyk Służby Celno-Skarbowej i SOP stanowisko wiążące przyjęcie propozycji zatrudnienia pracowniczego z obowiązkiem wydania decyzji rozwiązującej niepracowniczy stosunek służbowy wydaje się możliwe do zaakceptowania. Należy jednak podkreślić, że w świetle dyrektywy zapewnienia gwarancji stabilizacji zatrudnienia służbowego o charakterze administracyjnoprawnym zabieg tego rodzaju zmierzający do wypełnienia luki w prawie, byłby niewystarczający. Przedmiotem kontroli zostałaby przede wszystkim prawidłowość wydania deklaratoryjnej decyzji zwalniającej funkcjonariusza ze służby. Dlatego też tak istotne jest dopuszczenie możliwości kontroli w toku instancji sądowej, czy organ, składając ofertę zatrudnienia na podstawie umowy o pracę, zastosował kryteria określone w pragmatykach służbowych, co powinno znaleźć odzwierciedlenie w uzasadnieniu tej mającej charakter aktu administracyjnego propozycji.

Przedstawione argumenty dotyczące charakteru prawnego propozycji zatrudnienia o charakterze pracowniczym należy odnieść również do czynności właściwego przełożonego polegającej na przedstawieniu informacji o braku propozycji

23 Zob. między innymi powoływaną wcześniej uchwałę NSA z dnia 1 lipca 2019 roku, I OPS 1/19; oraz wyrok NSA z dnia 17 stycznia 2019 roku, I OSK 996/18, Legalis nr 1882124.

24 Zob. postanowienia WSA w Łodzi z dnia 16 listopada 2018 roku, III SA/Łd 750/17, LEX nr 2591860; wyrok WSA w Gdańsku z dnia 20 grudnia 2017 roku, III SAB/Gd 71/17, LEX nr 2417710. 
pełnienia służby lub zatrudnienia ${ }^{25}$. Na drodze tego aktu rozstrzygana jest indywidualna sprawa funkcjonariusza, wymykająca się z ram podległości służbowej. Ustawodawca nie uregulował przesłanek wydania takiej informacji. Należy się zgodzić ze stanowiskiem, że brak regulacji w tym zakresie budzi poważne wątpliwości, w szczególności w świetle przepisów pragmatyk przewidujących obowiązek uwzględnienia kryteriów wskazanych przez ustawodawcę przy przedstawianiu propozycji dalszego pełnienia służby lub zatrudnienia pracowniczego ${ }^{26}$. Skoro ustawodawca obliguje, aby przedstawiając tę propozycję, uwzględnić wskazane kryteria, to tym bardziej taki tryb postępowania powinien mieć zastosowanie w wypadku nieprzedstawienia odpowiedniej propozycji funkcjonariuszowi $^{27}$. Ocena uwzględniająca wszelkie okoliczności sprawy powinna znaleźć się w uzasadnieniu mającej charakter aktu administracyjnego, mogącej stanowić samodzielny przedmiot zaskarżenia, informacji o braku propozycji ${ }^{28}$.

$\mathrm{Na}$ tle regulacji ustawy wprowadzającej KAS w orzecznictwie przyjęto, że wystarczająca dla ochrony interesu prawnego funkcjonariuszy tej formacji była kontrola decyzji wygaszającej stosunek służbowy, stanowiącej konsekwencję nieprzedstawienia propozycji służby lub pracy. Wydając tę decyzję, organ każdorazowo był zobowiązany wziąć pod uwagę i rozważyć kryteria, o jakich mowa w art. 165 ust. 7 ustawy wprowadzającej KAS ${ }^{29}$. Podobnie jak w przypadku analizowanej wcześniej decyzji rozwiązującej stosunek służbowy w wyniku przyjęcia propozycji zatrudnienia kontrola sprawowana przez sąd na tym etapie jest niewystarczająca. Skoncentrowana jest bowiem na przesłankach prawidłowości wydania decyzji prowadzącej do wygaśnięcia stosunku służbowego, a nie na przesłankach, którymi kierował się uprzednio organ, nie przedstawiając propozycji służby lub pracy.

\section{PODSUMOWANIE}

Ustawodawca, przeprowadzając reformy mające na celu reorganizację służb mundurowych, nie może nie uwzględniać faktu, że z mianowaniem na stanowisko wiąże się nawiązanie niepracowniczego stosunku zatrudnienia typu administra-

${ }^{25}$ Zob. art. 359 ust. 6 ustawy o SOP. Obowiązek dostarczenia informacji o braku propozycji pełnienia służby lub zatrudnienia pracowniczego spoczywał na organie tylko w przypadku, kiedy dotyczył on funkcjonariuszy pełniących służbę w urzędzie obsługującym ministra właściwego do spraw finansów publicznych (zob. art. 170 ust. 7 ustawy wprowadzającej KAS). Z niewiadomych względów ustawodawca nie nałożył powinności tego rodzaju na przełożonych służbowych funkcjonariuszy zatrudnionych w pozostałych działach administracji celno-skarbowej.

26 Tak P. Złamańczuk, [w:] Ustawa o Stużbie Ochrony Państwa. Komentarz, red. M. Rogalski, P. Szustakiewicz, P. Złamańczuk, Warszawa 2019, Legalis, komentarz do art. 359.

27 Ibidem.

28 Odmiennie P. Złamańczuk, op. cit., Legalis, komentarz do art. 359

29 Zob. wyrok NSA dnia 22 października 2019 roku, I OSK 2121/18, LEX nr 2735754. 
cyjnego, który objęty jest dalej idącymi gwarancjami trwałości niż umowne stosunki pracy. Warto podkreślić, że źródeł stabilizacji zatrudnienia należy upatrywać w regulacjach nie tylko pragmatycznych, ale przede wszystkim konstytucyjnych. Przyjmuje się, że przepis art. 60 Konstytucji RP reguluje nie tylko etap naboru do służby publicznej, lecz również zasady wykonywania tej służby, a także zwalniania ze służby publicznej ${ }^{30}$. Oznacza to, że organ, podejmując rozstrzygnięcia w zakresie stosunków służbowych łączących funkcjonariusza $z$ daną służbą, nie może działać w sposób arbitralny i nawet potrzeba reorganizacji danej służby nie może być wykorzystywana jako okazja do dowolnej wymiany funkcjonariuszy, czego ustawodawca wydaje się nie dostrzegać. Rozważenia w orzecznictwie, szczególnie NSA, wymagałaby zatem kwestia konieczności wypełnienia luki prawnej w drodze bezpośredniego zastosowania przepisu art. 60 Konstytucji RP w celu prawidłowego zagwarantowania prawa do sądu funkcjonariuszowi, a tym samym zapewnienia należytej ochrony trwałości służbowego stosunku zatrudnienia. Przede wszystkim jednak dokonywanie reorganizacji lub innych zmian o charakterze personalnym w służbach mundurowych powinno uwzględniać konieczność ochrony roszczeń podmiotów pozostających w publicznoprawnych stosunkach zatrudnienia.

\title{
PROTECTION OF THE PERMANENCE OF EMPLOYMENT OF UNIFORMED SERVICES OFFICERS IN THE CASE OF REORGANISATION OF UNITS EMPLOYING THEM - SELECTED ISSUES
}

\begin{abstract}
Summary
The subject of the study is the issue of protecting the durability of non-working service relationships of uniformed officers, whose uniformed formations have undergone a deep reorganisation in recent years. The author made a critical assessment of transitional legal solutions aimed at adjusting the existing human resources to the current needs and requirements, which in fact exclude the immanent feature of the official employment, which is its stabilisation. In this regard, special attention should be given to issues related to the legal nature of the relevant superior's proposal to perform the service or employee employment or information about the lack of such an offer and the need to issue a decision terminating the service relationship in the event of its transformation into an
\end{abstract}

${ }^{30}$ Zob. uzasadnienie wyroku z dnia 23 stycznia 2014 roku, K 51/12, OTK-A 2014, nr 1, poz.4. 
employment relationship under an indefinite contract or fixed period. The subject of the assessment is also the jurisprudence of administrative courts based on the legal solutions adopted by the legislator in the indicated scope.

Keywords: stabilisation of employment, uniformed officer, termination of service relationship, offer of service or employment

\section{BIBLIOGRAFIA}

Ustawa o Stużbie Ochrony Państwa. Komentarz, red. M. Rogalski, P. Szustakiewicz, P. Złamańczuk, Warszawa 2019. 